This Health Hazard Evaluation (HHE) report and any recommendations made herein are for the specific facility evaluated and may not be universally applicable. Any recommendations made are not to be considered as final statements of NIOSH policy or of any agency or individual involved. Additional HHE reports are available at http://www.cdc.gov/niosh/hhe/reports

\title{
HEALTH HAZARD EVALUATION
} REPORT

HETA 92-0029

KESSLER STUDIOS

LOVELAND, OHIO 
HETA 92-0029-2392

FEBRUARY 1994

KESSLER STUDIOS

LOVELAND, OHIO
NIOSH INVESTIGATOR:

Beth A. Donovan, M.H.S.

\section{SUMMARY}

The National Institute for Occupational Safety and Health (NIOSH) conducted a Health Hazard Evaluation (HHE) at Kessler Studios in Loveland, Ohio. The request, from the owners and only full-time workers of the stained glass window-making studio, was to assess their exposure to lead dust and fumes in the studio and in their adjoining house. The air samples collected in the studio during all of the work procedures except one measured low concentrations of lead. The whiting process, which is a cleaning procedure, generated breathing-zone lead dust concentrations ranging from 60 to 80 micrograms per cubic meter $\left(\mu \mathrm{g} / \mathrm{m}^{3}\right)$, higher than the Occupational Safety and Health Administration (OSHA) Permissible Exposure Limit (PEL) of $50 \mu \mathrm{g} / \mathrm{m}^{3}$. The surface wipe samples in the studio revealed an accumulation of lead dust (1.2 to 1600 milligrams per square meter $\left[\mathrm{mg} / \mathrm{m}^{2}\right]$ ). The surface wipe samples, dust vacuum samples, and general area air samples collected in the house suggest that lead dust is not migrating into the house. The blood lead levels (BLLs) collected on the fifth day of sampling were 1.8 micrograms per deciliter $(\mu \mathrm{g} / \mathrm{dl})$ and $2.1 \mu \mathrm{g} / \mathrm{dl}$, and the zinc protoporphyrin (ZPP) blood levels were $34 \mu \mathrm{g} / \mathrm{dl}$ and $31 \mu \mathrm{g} / \mathrm{dl}$. These levels are below the levels of concern.

Although the surface samples in the studio suggest that lead dust does accumulate, the air samples and blood lead levels indicate that personal lead exposures are low, except during the whiting process. The results indicate that the ventilation and hygiene practices employed by the artists are minimizing their exposures to lead and are preventing the contamination of their house with lead. Their simple ventilation and hygiene techniques should be continued and could probably benefit others in the trade.

KEYWORDS: SIC 3231 (Glass Products, Made of Purchased Glass), lead, stained glass window, surface wipe sampling, dust vacuum sampling, blood lead levels 


\section{Page 2 - Health Hazard Evaluation Report No. 92-0029}

\section{INTRODUCTION}

At the request of the owners of Kessler Studios in Loveland, Ohio, the National Institute for Occupational Safety and Health conducted an health hazard evaluation (HHE) to assess lead exposure during the process of stained glass window making. The Kesslers own and operate a small stained glass window studio that is adjoined to their house. Occasionally they will hire part-time employees or contract their work to other studios, but most often do all the work themselves. Lead exposure from working with leaded "came," the malleable support that holds the pieces of glass together, lead/tin solder, and possible lead contamination in their home were the primary concerns.

The NIOSH investigator visited the studio on five days, two during the glass cutting and leading process, and three during the soldering, leading, and whiting processes. Personal breathing zone (PBZ) and general area (GA) air samples were collected in and outside of the studio, and in the adjoining house. Surface wipe samples were taken in the studio and the house. Vacuum samples of the carpets were also taken in the house. Bulk samples of the whiting agent were collected before and after its use. Soil samples were collected around the house and the studio on the first and fifth day of sampling. All of these samples were analyzed for lead. In addition, the air samples collected during soldering were also analyzed for zinc.

\section{BACKGROUND}

Stained glass window-making began as a hobby for the Kesslers, but has now expanded into a full-time job. Their garage has been converted into a studio, complete with work tables, grinding wheels, a sink, two small flexible ventilation ducts, and a separate whiting room with a through-the-wall exhaust fan. After the glass is cut into the appropriate pieces, they are assembled and joined together with the lead came, a process called leading. The came is cut and molded to cover the edges and join the pieces of glass. Once all the came is in place, the junctures are joined with a lead/tin solder, using a copper/zinc flux and a soldering iron. Both sides of the window are soldered. The excess flux and the writing on the glass must then be cleaned off the window by a process called whiting. A mixture of talc, linseed oil, turpentine replacement, cement black color, and lead-free Japanese drier are rubbed over the window. Then the mixture is manually scrubbed over the surface with a metal bristle brush. More talc is added as the mixture is brushed over the window surface. When the window is clean, the remaining powder is brushed off with a soft bristle brush, and the window is ready to have supports added and to then be placed into the window frame.

The Kesslers have implemented several hygiene practices in their studio. There are two flexible ducts connected to exhaust fans that are used for local exhaust ventilation during soldering. In the whiting room there is a through-the-wall axial fan preceded by an electrostatic filter. An adhesive mat is used at both doorways to decrease the migration of lead dust out of the studio on shoe bottoms. A laundry room near the door that connects the studio to the house is used as a changing room to change into and out of studio clothes. Studio clothes, which are not worn anywhere outside of the studio, are washed separately from other clothes. Work shoes do not leave the studio; they are left at the door. There is no eating permitted in the studio, nor are the dog or child allowed into it. Latex gloves are worn during the entire process except for the initial cutting of the glass and discarded before leaving the studio. There is also a small sink in the studio for washing hands. 


\section{Page 3 - Health Hazard Evaluation Report No. 92-0029}

\section{EVALUATION CRITERIA}

As a guide to the evaluation of the hazards posed by workplace exposures, NIOSH field staff employ evaluation criteria for the assessment of a number of chemical (and physical) agents. The primary sources of environmental evaluation criteria for the workplace are the following: (1) NIOSH Criteria Documents and Recommended Exposure Limits (RELs), (2) the Occupational Safety and Health Administration (OSHA) Permissible Exposure Limits (PELs), and (3) the American Conference of Governmental Industrial Hygienists (ACGIH) Threshold Limit Values (TLVs). ${ }^{1,2,3}$ The objective of these criteria for chemical agents is to establish levels of exposure to which the vast majority of workers may be exposed without experiencing adverse health effects.

Full-shift and shorter duration criteria are available depending on the specific physiologic properties of the agent. Full-shift limits are based on the time-weighted average (TWA) airborne concentration of a substance that workers may be repeatedly exposed to during an eight or 10 hour work day, up to 40 hours a week for a working lifetime, without adverse health effects. Some substances have short-term exposure limits (STELs) or ceiling limits (CLs) which are intended to supplement the full-shift criteria where there are recognized irritative or toxic effects from brief exposures to high airborne concentrations. STELs are based on 15 minute TWA concentrations, whereas CL concentrations should not be exceeded even momentarily.

Occupational health criteria are established based on the available scientific information provided by industrial experience, animal or human experimental data, or epidemiologic studies. Differences between the NIOSH RELs, OSHA PELs, and ACGIH TLVs may exist because of different philosophies and interpretations of technical information. It should be noted that RELs and TLVs are guidelines, whereas PELs are standards which are legally enforceable. OSHA PELs are required to take into account the technical and economical feasibility of controlling exposures in various industries where the agents are present. The NIOSH RELs are primarily based upon the prevention of occupational disease without assessing the economic feasibility of the affected industries and as such tend to be very conservative. ACGIH is not a government agency, it is a professional organization whose members are industrial hygienists or other professionals in related disciplines and are employed in the public or academic sector. TLVs are developed by consensus agreement of the ACGIH TLV committee and are published annually. The documentation supporting the TLVs (and proposed changes) is periodically reviewed and updated if believed necessary by the committee. It is not intended by the ACGIH for TLVs to be applied as the threshold between safe and dangerous exposures.

Not all workers will be protected from adverse health effects if their exposures are maintained below these occupational health exposure criteria. A small percentage may experience adverse effects due to individual susceptibility, a pre-existing medical condition, previous exposures, and/or a hypersensitivity (allergy). In addition, some hazardous substances may act in combination with other workplace exposures, or with medications or personal habits of the worker (such as smoking) to produce health effects even if the occupational exposures are controlled to the limit set by the evaluation criterion. These combined effects are often not considered by the chemical specific evaluation criteria. Furthermore, many substances are appreciably absorbed by direct contact with the skin and thus potentially increase the overall exposure and biologic response beyond that expected from inhalation alone. Finally, evaluation criteria may change over time as new information on the toxic effects of an agent become available. Because of these reasons, it is prudent for an employer to maintain worker exposures well below established occupational health criteria. 


\section{Page 4 - Health Hazard Evaluation Report No. 92-0029}

\section{LEAD}

Inhalation of lead dust and fume, and ingestion resulting from hand-to-mouth contact with lead-contaminated food, cigarettes, clothing, or other objects are the major routes of worker exposure to lead. Once absorbed, lead accumulates in the soft tissues and bones, with the highest accumulation initially in the liver and kidneys. ${ }^{4}$ Lead is stored in the bones for decades, and may cause toxic effects as it is slowly released over time. Overexposure to lead results in damage to the kidneys, gastrointestinal tract, peripheral and central nervous systems, and the blood-forming organs (bone marrow).

The frequency and severity of symptoms associated with lead exposure increase with increasing blood lead levels (BLLs). Signs or symptoms of acute lead intoxication include weakness, excessive tiredness, irritability, constipation, anorexia, abdominal discomfort, colic, anemia, high blood pressure, irritability or anxiety, fine tremors, pigmentation of the gums ("lead line"), and "wrist drop."5-7

Overt symptoms of lead poisoning in adults generally begin at BLLs between 60 and 120 micrograms per deciliter $(\mu \mathrm{g} / \mathrm{dl})$. Neurologic, hematologic, and reproductive effects, however, may be detectable at much lower levels, and the World Health Organization (WHO) has recommended an upper limit of $40 \mu \mathrm{g} / \mathrm{dl}$ for occupationally exposed adult males. ${ }^{8}$ The mean serum lead level for U.S. men from 1976-1980 was $16 \mu \mathrm{g} / \mathrm{dl} .^{9,10}$ However, with the implementation of lead-free gasoline and reduced lead in food, it was predicted in 1991 that the 1991 average serum lead level of U.S. men will probably drop below $9 \mu \mathrm{g} / \mathrm{dl} .^{11}$

An increase in an individual worker's BLL can mean that the worker is being overexposed to lead. While the BLL is a good indication of recent exposure to, and current absorption of lead, it is not a reliable indication of the total body burden of lead. ${ }^{12}$ Lead can accumulate in the body over time and produce health effects long after exposure has stopped. Long-term overexposure to lead may cause infertility in both sexes, fetal damage, chronic kidney disease (nephropathy), and anemia.

Under the OSHA standard regulating occupational exposure to inorganic lead in general industry, the PEL is 50 micrograms per cubic meter $\left(\mu \mathrm{g} / \mathrm{m}^{3}\right)$ as an 8-hour TWA. ${ }^{13}$ The standard requires semi-annual monitoring of BLL for employees exposed to airborne lead at or above the Action Level of $30 \mu \mathrm{g} / \mathrm{m}^{3}$ (8-hour TWA), specifies medical removal of employees whose average BLL is $50 \mu \mathrm{g} / \mathrm{dl}$ or greater, and provides economic protection for medically removed workers. The NIOSH REL for lead is less than $100 \mu \mathrm{g} / \mathrm{m}^{3}$ as a TWA for up to 10 hours. This REL is an air concentration to be maintained so that worker blood lead remains below $60 \mu \mathrm{g} / 100$ grams of whole blood. NIOSH is presently reviewing literature on the health effects of lead to re-evaluate its REL. The OSHA PEL for general industry is currently recommended by NIOSH investigators as a more protective criteria.

Recent studies suggest that there are adverse health effects at BLLs below the current evaluation criteria for occupational exposure. A number of studies have found neurological symptoms in workers with BLLs of 40 to $60 \mu \mathrm{g} / \mathrm{dl}$. Male BLLs are associated with increases in blood pressure, with no apparent threshold through less than $10 \mu \mathrm{g} / \mathrm{dl}$. Studies have suggested decreased fertility in men at BLLs as low as 40 $\mu \mathrm{g} / \mathrm{dl}$. Prenatal exposure to lead is associated with reduced gestational age, birthweight, and early mental development at prenatal maternal BLLs as low as 10 to $15 \mu \mathrm{g} / \mathrm{dl} .^{14}$

In recognition of the health risks associated with exposure to lead, a goal for reducing occupational exposure was specified in Healthy People 2000, a recent statement of 


\section{Page 5 - Health Hazard Evaluation Report No. 92-0029}

national consensus and U.S. Public Health Service policy for health promotion and disease prevention. The goal for workers exposed to lead is to eliminate, by the year 2000, all exposures that result in BLLs greater than $25 \mu \mathrm{g} / \mathrm{dl} .{ }^{15}$

In homes with a family member occupationally exposed to lead, lead dust may be carried home on clothing, skin, and hair, and in vehicles. High BLLs in resident children, and elevated concentrations of lead in the house dust, have been found in the homes of workers employed in industries associated with high lead exposure. ${ }^{16}$ Particular effort should be made to ensure that children of workers with lead poisoning, or who work in areas of high lead exposure, are tested for lead exposure (BLL) by a qualified health-care provider.

There are no Federal standards governing the level of lead in surface dust in either occupational or non-occupational (i.e., residential settings). However, leadcontaminated surface dust in either setting represents a potential exposure to lead through ingestion, especially by children. This may occur either by direct hand-tomouth contact with the dust, or indirectly from hand-to-mouth contact via clothing, cigarettes, or food contaminated by lead dust. Previous studies have found a significant correlation between resident children's BLLs and house dust lead levels. ${ }^{17}$ Based on previous standards established in Massachusetts and Maryland, the U.S. Department of Housing and Urban Development (HUD) has recommended the following final clearance standards for lead in house dust on specific interior surfaces following lead abatement: floors, 200 micrograms per square foot $\left(\mu \mathrm{g} / \mathrm{ft}^{2}\right)$; window sills, $500 \mu \mathrm{g} / \mathrm{ft}^{2}$, and window wells, $800 \mu \mathrm{g} / \mathrm{ft}^{2}$. HUD also recommends the standard for floors be applied to exterior porches. ${ }^{18}$ These criteria were not based on epidemiology, but were empirically established as feasible limits for clearance following final cleaning during residential lead-based paint abatement. HUD recommends the use of these criteria until they are refined or replaced through additional research.

The adverse affects of lead on children and fetuses include decreases in intelligence and brain development, developmental delays, behavioral disturbances, decreased stature, anemia, elevated erythrocyte protoporphyrin levels, decreased gestational weight and age, and miscarriage or stillbirth. Lead exposure is especially devastating to fetuses and young children due to potentially irreversible toxic effects on the developing brain and nervous system. ${ }^{14}$ The Centers for Disease Control (CDC) recently (October 1991) published the fourth revision of Preventing Lead Poisoning in Young Children in recognition of new data indicating adverse effects in children at BLLs previously believed to be safe (e.g., $25 \mu \mathrm{g} / \mathrm{dl}$ ). ${ }^{19}$ No threshold has been identified for the harmful effects of lead in children; the CDC currently recommends a multitier approach to defining and preventing childhood lead poisoning, based on BLL screening. The BLLs and corresponding actions which CDC has recommended are: $\geq 10 \mu \mathrm{g} / \mathrm{dl}$, community prevention activities; $\geq 15 \mu \mathrm{g} / \mathrm{dl}$, individual case management including nutritional and educational interventions and more frequent screening; $\geq 20$ $\mu \mathrm{g} / \mathrm{dl}$, medical evaluation, environmental investigation and remediation. Additionally, environmental investigation and remediation are recommended for BLLs of 15-19 $\mu \mathrm{g} / \mathrm{dl}$, if such levels persist. The U.S. Public Health Service Year 2000 Objectives for the Nation aim for progressive declines in the number of lead poisoned children, leading to the elimination of this preventable disease. ${ }^{20}$

There are no Federal standards for occupational or childhood exposure to lead in soil. The CDC has previously stated (Preventing Lead Poisoning in Young Children--1985 edition) that soil concentrations exceeding 500-1,000 parts per million (ppm) appeared to cause increased BLLs in children. Based on this recommendation, the U.S. Environmental Protection Agency (EPA) Offices of Emergency and Remedial 


\section{Page 6 - Health Hazard Evaluation Report No. 92-0029}

Response and Waste Programs Enforcement currently use an interim guideline for Superfund hazardous waste sites which specifies cleanup of soil to a total lead concentration in the range of 500 to $1000 \mathrm{ppm}^{21}$

The State of Minnesota has promulgated a standard applicable to lead in soil on residential property and playgrounds intended to prevent exposures that might result in elevated (>25 $\mu \mathrm{g} / \mathrm{dl})$ childhood BLLs. The standard was based on a health risk assessment model intended to provide a reasonable degree of protection for young children considering the potential contribution of soil and other sources of lead exposure such as paint and house dust. The standard requires abatement for total lead concentrations at or above 0.03 percent by weight ( $300 \mathrm{ppm})$ of soil..$^{22}$

\section{EVALUATION METHODS}

Sampling was conducted at the studio over five days, two during the glass cutting and leading process, two during the leading and soldering, and one when both the soldering and whiting processes were occurring. Personal breathing zone (PBZ) and general area (GA) air samples were collected in and outside of the studio, and in the house. The air samples were collected on mixed cellulose ester filters (MCEFs) using Gillian High Air-Flow pumps at flow rates of either 2.0 liters per minute $(\mathrm{L} / \mathrm{min})$ or $3.0 \mathrm{~L} / \mathrm{min}$. The higher flow rate was used for short-term sampling during specific activities. Surface wipe samples were taken in the studio and the house using the NIOSH Wipe Sampling Method. A 100 square centimeter $\left(\mathrm{cm}^{2}\right)$ area was wiped three times (horizontal S-curve wipes, vertical S-curve wipes, and finally horizontal S-curve wipes again) with Wash 'N Dry ${ }^{\circledR}$ towelettes. Vacuum samples of the carpet surfaces were also taken in the house. Preweighed polyvinyl chloride (PVC) filters with small nozzle attachments were connected to a Gillian High Air-Flow pump calibrated to 3.0 $\mathrm{L} / \mathrm{min}$. The carpet surface was vacuumed in the same way that the other surfaces were wiped, three sets of S-curve wipes over a $100 \mathrm{~cm}^{2}$ area. Bulk samples of the whiting agent were collected before and after its use. Soil samples were collected around the house and around the studio on the first and fifth day of sampling. Blood samples were taken on the fifth day of sampling and analyzed for lead and zinc protoporphyrins concentrations.

All of the samples were analyzed for lead. In addition, the air samples collected during soldering were also analyzed for zinc. The bulk samples were also analyzed for calcium and magnesium.

\section{RESULTS AND DISCUSSION}

\section{AIR SAMPLES}

The PBZ and GA air sampling results are presented in Table 1. The GA samples from the studio, the house, and outside the studio were all $<0.1 \mu \mathrm{g} / \mathrm{m}^{3}$. Outside of the whiting room, during the whiting process, a trace concentration between 0.1 and $0.4 \mu \mathrm{g} / \mathrm{m}^{3}$ was detected. Quantifiable lead concentrations were measured during the leading/assembling process, the soldering process, and the whiting process. The leading measurements ranged from trace (detectable but not quantifiable) to $5.0 \mu \mathrm{g} / \mathrm{m}^{3}$. The highest concentration was measured on the fifth day of sampling.

The lead concentrations during soldering ranged from trace to $2.0 \mu \mathrm{g} / \mathrm{m}^{3}$. On the fifth day of sampling, the ventilation during one hour of soldering was altered and a PBZ sample was collected. Instead of the flexible exhaust duct being place on the table at 


\section{Page 7 - Health Hazard Evaluation Report No. 92-0029}

the point of soldering, it was suspended above the worker's head. Thus the fumes from the soldering that were usually observed to exit via the exhaust duct, could be seen accumulating over the work table. (The worker was wearing a respirator during this experiment.) The lead concentration measured after this ventilation alteration was $5.0 \mu \mathrm{g} / \mathrm{m}^{3}$. This value is not significantly higher than the concentrations measured with the usual ventilation or during the leading/assembling process. The zinc level was also measured on the PBZ samples since the flux contained zinc. When the duct was on the table, the zinc levels ranged from none detected to $0.005 \mathrm{mg} / \mathrm{m}^{3}$. When the ventilation was altered, the zinc concentration was $1.67 \mathrm{mg} / \mathrm{m}^{3}$, but still well below the PEL and REL of $50 \mu \mathrm{g} / \mathrm{m}^{3}$. The lack of any significant increase in lead exposure when the ventilation was altered was not surprising since it would be unlikely that the soldering iron is hot enough to volatilize the lead in the came or the solder.

The measured lead levels were highest during the whiting process. The full shift PBZ samples measured $60 \mu \mathrm{g} / \mathrm{m}^{3}$, and two task-specific PBZ samples (taken only during whiting) had concentrations of 70 and $80 \mu \mathrm{g} / \mathrm{m}^{3}$, respectively. These levels are above the OSHA PEL of $50 \mu \mathrm{g} / \mathrm{m}^{3}$.

\section{SURFACE WIPE SAMPLES}

The surface wipe samples are recorded in $\mathrm{mg} / \mathrm{m}^{2}$. The values may be compared to the HUD recommendation of $2.15 \mathrm{mg} / \mathrm{m}^{2}\left(200 \mu \mathrm{g} / \mathrm{ft}^{2}\right)$ for floor surfaces. The HUD recommendation is not based on health effects, nor is it for a workplace surface. Thus, it should only serve as a reference, not as a standard that should be met in a workplace.

All of the wipe samples from the house were none detected or trace. The levels from the studio ranged from 1.2 to $1600 \mathrm{mg} / \mathrm{m}^{2}$ of lead. The concentrations were highest on the small studio table that was used for storage of the glass pieces before assembly and for assembled windows, ranging from 29 to $1600 \mathrm{mg} / \mathrm{m}^{2}$. The large studio table where glass cutting, assembling, and soldering was done had the next highest concentrations, ranging from 3.5 to $270 \mathrm{mg} / \mathrm{m}^{2}$. The floor samples had the lower concentrations -- 7.9 to $170 \mathrm{mg} / \mathrm{m}^{2}$ on the floor between the two tables, and 1.2 to $3.7 \mathrm{mg} / \mathrm{m}^{2}$ on the hall floor that leads to the house. The whiting table had concentrations that ranged from 5.4 to $140 \mathrm{mg} / \mathrm{m}^{2}$. The studio was not cleaned on or before any of the sampling days. It is usually not cleaned during a project, only after its completion.

\section{BULK SAMPLES}

Three bulk samples of the whiting agent were collected, one of the powder before use, and two after use. Since there is no lead in the contents before use (which was confirmed by the first bulk sample), the second and third samples serve as an indication if any lead dust is added to the mixture as it is being used during the whiting process. There was no lead detected in the mixture before use. The second bulk sample was of a mixture that had been used weeks earlier and was left out on the table. It had a concentration of $420 \mu \mathrm{g}$ of lead per gram of mixture $(\mu \mathrm{g} / \mathrm{g})$. The third sample was collected immediately after use and it had a concentration of $1100 \mu \mathrm{g} / \mathrm{g}$. This indicates that during the whiting process, lead dust is generated. It is probably scraped from the came when the window is scrubbed with the metal bristle brush. The calcium and magnesium concentrations were the same before and after use. 
Table 1

General Area (GA) and Personal Breathing Zone (PBZ) Air Samples

Analyzed for Lead Levels

Kessler Studios

HETA 92-0029

9/27/93 - 10/5/93

\begin{tabular}{|c|c|c|c|c|c|c|}
\hline $\begin{array}{c}\text { Sample and } \\
\text { Location }\end{array}$ & Date & $\begin{array}{c}\text { Sample } \\
\text { Time } \\
\text { (min) }\end{array}$ & $\begin{array}{c}\text { Sample } \\
\text { Volume } \\
(\mathrm{L})\end{array}$ & $\begin{array}{c}\begin{array}{c}\text { Lead } \\
\text { Level } \\
\left(\mu \mathrm{g} / \mathbf{m}^{3}\right)\end{array} \\
\end{array}$ & $\begin{array}{l}\text { MDC* } \\
\left(\mu \mathrm{g} / \mathbf{m}^{3}\right)\end{array}$ & $\begin{array}{l}\text { MQC** } \\
\left(\mu \mathrm{g} / \mathbf{m}^{3}\right)\end{array}$ \\
\hline $\begin{array}{l}\text { PBZ, glass } \\
\text { cutting }\end{array}$ & $9 / 27 / 93$ & 378 & 756 & $\operatorname{trace}^{\dagger}$ & 0.1 & 0.5 \\
\hline GA, studio & $9 / 27 / 93$ & 475 & 950 & $\operatorname{trace}^{\dagger}$ & 0.1 & 0.4 \\
\hline $\begin{array}{l}\text { PBZ, leading/ } \\
\text { assembling }\end{array}$ & $9 / 28 / 93$ & 434 & 868 & 2 & 0.1 & 0.5 \\
\hline $\begin{array}{l}\text { PBZ, leading/ } \\
\text { assembling }\end{array}$ & 9/28/93 & 197 & 394 & $\operatorname{trace}^{\dagger}$ & 0.3 & 1 \\
\hline GA, studio & $9 / 28 / 93$ & 456 & 912 & $\operatorname{trace}^{\dagger}$ & 0.1 & 0.4 \\
\hline $\begin{array}{l}\text { GA, outside } \\
\text { studio }\end{array}$ & 9/28/93 & 463 & 926 & $\mathrm{ND}^{\ddagger}$ & 0.1 & 0.4 \\
\hline $\begin{array}{c}\text { GA, outside } \\
\text { house }\end{array}$ & $9 / 28 / 93$ & 336 & 672 & $\mathrm{ND}^{\ddagger}$ & 0.1 & 0.6 \\
\hline $\begin{array}{l}\text { PBZ, leading/ } \\
\text { assembling }\end{array}$ & $10 / 1 / 93$ & 387 & 774 & 0.8 & 0.1 & 0.5 \\
\hline PBZ, soldering & $10 / 1 / 93$ & 409 & 818 & 0.6 & 0.1 & 0.5 \\
\hline PBZ, soldering & $10 / 1 / 93$ & 154 & 462 & $\operatorname{trace}^{\dagger}$ & 0.2 & 0.9 \\
\hline PBZ, soldering & $10 / 1 / 93$ & 111 & 333 & $\operatorname{trace}^{\dagger}$ & 0.3 & 1 \\
\hline PBZ, soldering & $10 / 1 / 93$ & 51 & 153 & $\mathrm{ND}^{\ddagger}$ & 0.7 & 3 \\
\hline GA, studio & $10 / 1 / 93$ & 470 & 940 & $\operatorname{trace}^{\dagger}$ & 0.1 & 0.4 \\
\hline $\begin{array}{c}\text { GA, outside } \\
\text { studio }\end{array}$ & $10 / 1 / 93$ & 436 & 872 & $\mathrm{ND}^{\ddagger}$ & 0.1 & 0.5 \\
\hline GA, house & $10 / 1 / 93$ & 472 & 944 & $\mathrm{ND}^{\ddagger}$ & 0.1 & $\begin{array}{c}0.4 \text { Table } \\
\mathbf{1} \\
\text { (continue } \\
\mathbf{d})\end{array}$ \\
\hline $\begin{array}{l}\text { Sample and } \\
\text { Location }\end{array}$ & Date & $\begin{array}{c}\text { Sample } \\
\text { Time } \\
(\text { min) }\end{array}$ & $\begin{array}{c}\text { Sample } \\
\text { Volume } \\
\text { (L) }\end{array}$ & $\begin{array}{c}\text { Lead } \\
\text { Level } \\
\left(\mu \mathrm{g} / \mathrm{m}^{3}\right)\end{array}$ & $\begin{array}{l}\text { MDC** } \\
\left(\mu \mathrm{g} / \mathrm{m}^{3}\right)\end{array}$ & $\begin{array}{l}\text { MQC** } \\
\left(\mu \mathrm{g} / \mathbf{m}^{3}\right)\end{array}$ \\
\hline $\begin{array}{l}\text { PBZ, leading/ } \\
\text { assembling }\end{array}$ & $10 / 4 / 93$ & 385 & 770 & 2 & 0.1 & 0.4 \\
\hline PBZ, soldering & $10 / 4 / 93$ & 454 & 908 & 2 & 0.6 & 1 \\
\hline PBZ, soldering & $10 / 4 / 93$ & 80 & 240 & $\operatorname{trace}^{\dagger}$ & 0.3 & 1 \\
\hline GA, studio & $10 / 4 / 93$ & 476 & 952 & 0.7 & 0.08 & 0.3 \\
\hline
\end{tabular}




\begin{tabular}{|c|c|c|c|c|c|c|}
\hline $\begin{array}{c}\text { GA, outside } \\
\text { studio }\end{array}$ & $10 / 4 / 93$ & 422 & 844 & $\mathrm{ND}^{\ddagger}$ & 0.09 & 0.3 \\
\hline GA, house & $10 / 4 / 93$ & 308 & 616 & $\mathrm{ND}^{\ddagger}$ & 0.1 & 0.5 \\
\hline $\begin{array}{l}\text { PBZ, leading/ } \\
\text { assembling }\end{array}$ & $10 / 5 / 93$ & 481 & 962 & 5 & 0.5 & 1 \\
\hline $\begin{array}{l}\text { PBZ, leading, } \\
\text { mainly whiting }\end{array}$ & $10 / 5 / 93$ & 346 & 692 & 60 & 0.7 & 2 \\
\hline$\underset{* *}{\mathrm{PBZ}, \text { soldering }}$ & $10 / 5 / 93$ & 55 & 165 & 5 & 0.5 & 2 \\
\hline PBZ, whiting & $10 / 5 / 93$ & 128 & 384 & 80 & 1 & 3 \\
\hline PBZ, whiting & $10 / 5 / 93$ & 124 & 372 & 70 & 1 & 3 \\
\hline GA, studio & $10 / 5 / 93$ & 481 & 962 & 0.0009 & 0.08 & 0.3 \\
\hline $\begin{array}{c}\text { GA, outside } \\
\text { studio }\end{array}$ & $10 / 5 / 93$ & 477 & 954 & $\mathrm{ND}^{\ddagger}$ & 0.08 & 0.3 \\
\hline $\begin{array}{l}\text { GA, outside } \\
\text { whiting }\end{array}$ & $10 / 5 / 93$ & 374 & 748 & $\operatorname{trace}^{\dagger}$ & 0.1 & 0.4 \\
\hline GA, house & $10 / 5 / 93$ & 476 & 952 & $\mathrm{ND}^{\ddagger}$ & 0.08 & 0.3 \\
\hline
\end{tabular}

\footnotetext{
$\mu \mathrm{g} / \mathrm{m}^{3}=$ micrograms per cubic meter

* = MDC is minimal detectable concentration and MQC is minimal quantifiable concentration

$=$ Trace refers to an amount that is above the MDC but below the MQC. There is enough lead to be detected by the analysis method, but not enough to be quantified with a significant degree of accuracy.

$\ddagger=$ ND is none detected, meaning that the lead level is below the MDC.

$* *=$ During this soldering process, the flexible ventilation duct, which was usually on the table right at the point of soldering, was suspended from the ceiling to assess the exposure to the worker when the fumes were permitted to enter into the breathing zone. The worker wore a respirator during this process.
}

BOLD FACE indicates levels above the OSHA PEL of $0.050 \mathrm{mg} / \mathrm{m}^{3}$ 
Page 10 - Health Hazard Evaluation Report No. 92-0029

Table 2

Surface Wipe Samples Analyzed for Lead Concentrations

on Each Date of Sampling

Kessler Studios

HETA 92-0029

9/27/93 - 10/5/93

\begin{tabular}{|c|c|c|c|c|c|}
\hline \multirow[t]{2}{*}{ Sample Location } & \multicolumn{5}{|c|}{ Lead Concentration $\left(\mathrm{mg} / \mathrm{m}^{2}\right)$} \\
\hline & $9 / 27 / 93$ & $9 / 28 / 93$ & $10 / 1 / 93$ & $10 / 4 / 93$ & $10 / 5 / 93$ \\
\hline studio, hall to house & 1.2 & 2.3 & 2.8 & 1.5 & 3.7 \\
\hline studio floor & 7.9 & 23 & 13 & 64 & 170 \\
\hline studio table, large & 3.5 & 7.5 & 270 & 51 & 230 \\
\hline studio table, small & 69 & 110 & 1600 & 29 & 32 \\
\hline studio, whiting table & 8.4 & 5.4 & 140 & 7.7 & 120 \\
\hline house, changing room & ND* & $\operatorname{trace}^{\dagger}$ & $\operatorname{trace}^{\dagger}$ & 1.6 & 2.9 \\
\hline house, hall to studio & ND* & $\operatorname{trace}^{\dagger}$ & $\operatorname{trace}^{\dagger}$ & $\operatorname{trace}^{\dagger}$ & $\operatorname{trace}^{\dagger}$ \\
\hline house, hall & trace $^{\dagger}$ & ND* & ND* & trace $^{\dagger}$ & 0.26 \\
\hline house, dining room floor & ND* & ND* & $\operatorname{trace}^{\dagger}$ & ND* & 0.48 \\
\hline house, kitchen floor & $\mathrm{ND}^{*}$ & ND* & $\operatorname{trace}^{\dagger}$ & ND* & 0.19 \\
\hline house, living room floor & $\operatorname{trace}^{\dagger}$ & ND* & ND* & ND* & 0.48 \\
\hline house, foyer & ND* & ND* & ND* & ND* & 0.24 \\
\hline MDC & 0.10 & 0.10 & 0.10 & 0.08 & 0.08 \\
\hline MQC & 4.6 & 4.6 & 4.6 & 0.26 & 0.26 \\
\hline $\begin{aligned} \mathrm{mg} / \mathrm{m}^{2} & =\text { milligrams per square } \mathrm{m} \\
\mathrm{MDC} & =\text { minimal detectable conc } \\
\mathrm{MQC} & =\text { minimal quantifiable col } \\
& =\text { ND is none detected, me } \\
& =\text { Trace refers to an amour } \\
& \text { method, but not enough }\end{aligned}$ & $\begin{array}{l}\text { on } \\
\text { tion } \\
\text { hat the leac } \\
\text { s above the } \\
\text { uantified w }\end{array}$ & ut below $t$ & accuracy & $5=$ & 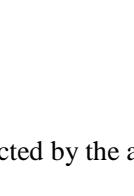 \\
\hline
\end{tabular}




\section{Page 11 - Health Hazard Evaluation Report No. 92-0029}

\section{CARPET DUST VACUUM SAMPLES}

All of the carpet dust vacuum samples collected on 9/27/93 and 10/1/93 were below the minimal quantifiable concentration $\left(<4600 \mu \mathrm{g} / \mathrm{m}^{2}\right)$, and most were below the minimal detectable concentration $\left(<1000 \mu \mathrm{g} / \mathrm{m}^{2}\right)$. On 10/5/93, one sample was below the minimal quantifiable concentration $\left(<1700 \mu \mathrm{g} / \mathrm{m}^{2}\right)$, and three were below the minimal detectable concentration $\left(<500 \mu \mathrm{g} / \mathrm{m}^{2}\right)$.

\section{SOIL SAMPLES}

Composite soil samples were collected around the house and around the studio at near ( 0 to three feet) and far (10 to 20 feet) locations for lead analysis. On 9/27/93, the samples around the house contained $73 \mu \mathrm{g} / \mathrm{g}$ of soil and $53 \mu \mathrm{g} / \mathrm{g}$ of soil for the near and far samples, respectively. The near and far samples around the studio were $58 \mu \mathrm{g} / \mathrm{g}$ and $62 \mu \mathrm{g} / \mathrm{g}$, respectively. The values were not much different on 10/5/93. They were trace $(<35 \mu \mathrm{g} / \mathrm{g}), 57$ $\mu \mathrm{g} / \mathrm{g}, 68 \mu \mathrm{g} / \mathrm{g}$, and $110 \mu \mathrm{g} / \mathrm{g}$, respectively for the near house, far house, near studio, and far studio samples. Since these four composite samples are spot samples, they should not be used to characterized the surface soil lead levels of the whole yard. These levels do suggest that the lead levels in the soil around the studio are not drastically different than the levels around the house.

\section{BLOOD LEAD LEVELS (BLLS)}

The two full-time workers at the studio had had their BLLs checked in the past and their levels were always less than $10 \mu \mathrm{g} / \mathrm{dl}$ of blood. The BLLs collected by a NIOSH investigator on the fifth day of sampling were also less than $10 \mu \mathrm{g} / \mathrm{dl}$. One worker had a BLL of $1.8 \mu \mathrm{g} / \mathrm{dl}$ and a zinc protoporphyrin (ZPP) level of $34 \mu \mathrm{g} / \mathrm{dl}$. The other had a BLL of $2.1 \mu \mathrm{g} / \mathrm{dl}$ and a ZPP of $31 \mu \mathrm{g} / \mathrm{dl}$. Although the air sample during the whiting process suggested a high worker exposure to lead, this process only occurred on the fifth day of sampling, the same day the blood samples were collected. The potential dose of lead from whiting had probably not been absorbed into the bloodstream yet.

\section{RECOMMENDATIONS}

1. Since the lead dust levels during the whiting process are greater than the OSHA PEL, it is recommended that an appropriate respirator be worn. The MSHA/NIOSH approved halfface respirator with an organic vapor cartridge is not sufficient. A dual cartridge, high efficiency particulate air (HEPA) filter and organic vapor, should be used. Respirators need to be properly fit-tested to ensure that there is a leak-proof seal. Protection is not certain without proper fit testing. Also, anyone that wears a respirator should be determined medically fit to wear one. Any part-time employees also should be properly fit-tested and medically tested before using a respirator.

2. Although the surface samples in the studio suggest that lead dust does accumulate, the air samples and BLL suggest that personal lead exposures are low except during the whiting process. The results indicate that the ventilation and hygiene practices employed by the artists are minimizing their exposures to lead and are preventing the contamination of their house with lead. These should be continued and could probably benefit others in the trade. 


\section{Page 12 - Health Hazard Evaluation Report No. 92-0029}

\section{REFERENCES}

1. CDC [1992]. NIOSH recommendations for occupational safety and health:

Compendium of policy documents and statements. Cincinnati, OH: U.S. Department of Health and Human Services, Public Health Service, Centers for Disease Control, National Institute for Occupational Safety and Health, DHHS (NIOSH) Publication No. 92-100.

2. Code of Federal Regulations [1989]. OSHA Table Z-1-A. 29 CFR 1910.1000. Washington, DC: U.S. Government Printing Office, Federal Register.

3. ACGIH [1991]. 1991-1992 Threshold limit values for chemical substances and physical agents and biological exposure indices. Cincinnati, OH: American Conference of Governmental Industrial Hygienists.

4. NIOSH [1981]. Occupational health guidelines for chemical hazards. Cincinnati, OH: U.S. Department of Health and Human Services, Public Health Service, Centers for Disease Control, National Institute for Occupational Safety and Health, DHHS (NIOSH) Publication No. 81-123, and supplements 88-118, 89-104.

5. Hernberg S, et al [1988]. Lead and its compounds. In: Occupational medicine. 2nd ed. Chicago, IL: Year Book Medical Publishers.

6. Landrigan PJ, et al [1985]. Body lead burden: summary of epidemiological data on its relation to environmental sources and toxic effects. In: Dietary and environmental lead: human health effects. Amsterdam: Elsevier Science Publishers.

7. Proctor NH, Hughes JP, Fischman ML [1988]. Lead. In: Chemical hazards of the workplace. 2nd ed. Philadelphia, PA: J.B. Lippincott Company, Philadelphia, pp 294298.

8. WHO [1980]. Recommended health-based limits in occupational exposure to heavy metals. Geneva: World Health Organization. Technical Report Series 647.

9. Muhaffey K, Annest J, Roberts J, Murphy R [1982]. National estimates of blood lead levels. United States, 1976-1980. New Engl J Med 307:373-9.

10. Annest J, Dirkle J, Makuc C, Nesse J, Bayse D, Kovar M [1983]. Chronological trends in blood lead levels between 1976 and 1980. New Engl J Med 308:1373-7.

11. CDC [1991]. Strategic plan for the elimination of childhood lead poisoning. U.S. Department of Health and Human Services, Public Health Service, Centers for Disease Control.

12. NIOSH [1978]. Occupational exposure to inorganic lead. Cincinnati, OH: U.S. Department of Health, Education, and Welfare, Public Health Service, Centers for Disease Control, National Institute for Occupational Safety and Health, DHEW (NIOSH) Publication No. 78-158.

13. Code of Federal Regulations [1989]. OSHA lead standard. 29 CFR, Part 1910.1025. Washington, DC: U.S. Government Printing Office, Federal Register.

14. ATSDR [1990]. Toxicological profile for lead. Atlanta, GA: U.S. Department of Health and Human Services, Public Health Service, Agency for Toxic Substances and Disease Registry, DHHS (ATSDR) Publication No. TP-88/17. 


\section{Page 13 - Health Hazard Evaluation Report No. 92-0029}

15. DHHS [1990]. Healthy people 2000: national health promotion and disease objectives. Washington, DC: U.S. Department of Health and Human Services, Public Health Service, DHHS Publication No. (PHS) 91-50212.

16. Grandjean P, Bach E [1986]. Indirect exposures: the significance of bystanders at work and at home. Am Ind Hyg Assoc J 47(12):819-824.

17. Farfel MR, Chisholm JJ [1990]. Health and environmental outcomes of traditional and modified practices for abatement of residential lead-based paint. American Jour of Pub Health 80:10, 1240-1245.

18. HUD [1990]. Lead-based paint: Interim guidelines for hazard identification and abatement in public and indian housing. Washington, DC: U.S. Department of Housing and Urban Development, Office of Public and Indian Housing, September 1990.

19. CDC [1991]. Preventing lead poisoning in young children: a statement by the Centers for Disease Control - October 1991. Atlanta, GA: U.S. Department of Health and Human Service, Public Health Service, Centers for Disease Control.

20. CDC [1991]. Strategic plan for the elimination of childhood lead poisoning. Atlanta, GA: U.S. Department of Health and Human Service, Public Health Service, Centers for Disease Control.

21. EPA [1989]. Memorandum, OSWER Directive \#9355.4-02, Interim guidance on establishing oil lead cleanup levels at superfund sites. Office of Solid Waste and Emergency Response, United States Environmental Protection Agency, September 7, 1989.

22. MPCA [1991]. Lead abatement in soil. Minnesota Rules, chapter 4760, parts 4760.0010-4760.0050. St. Paul, MN: Minnesota Pollution Control Agency, Hazardous Waste Division, Rules Unit. 
Page 14 - Health Hazard Evaluation Report No. 92-0029

\section{INVESTIGATORS AND ACKNOWLEDGEMENTS}

Investigator:

Beth A. Donovan, M.H.S.

Industrial Hygienist

Industrial Hygiene Section

Field Assistant:

Gregory Burr, C.I.H.

Supervisory Industrial Hygienist

Industrial Hygiene Section

Dino Mattorano

Industrial Hygienist

Industrial Hygiene Section

Sam Waltzer

Industrial Hygiene Intern

Industrial Hygiene Section

Originating Office:

Hazard Evaluations and Technical

Assistance Branch

Division of Surveillance, Hazard

Evaluations and Field Studies

\section{DISTRIBUTION AND POSTING}

Copies of this report may be freely reproduced and are not copyrighted. Single copies of this report will be available for a period of 90 days from the date of this report from the NIOSH Publications Office, 4676 Columbia Parkway, Cincinnati, Ohio 45226. To expedite your request, include a self-addressed mailing label along with your written request. After this time, copies may be purchased from the National Technical Information Service (NTIS), 5285 Port Royal Road, Springfield, Virginia 22161. Information regarding the NTIS stock number may be obtained from the NIOSH Publications Office at the Cincinnati address.

Copies of this report have been sent to:

1. Kessler Studios

For the purpose of informing affected employees, copies of this report shall be posted by the employer in a prominent place accessible to the employees for a period of $\mathbf{3 0}$ calendar days. 